\title{
SHORT COMUNICATION \\ INFLUENCE OF LYOPHILIZATION AND CONVECTIVE TYPE DRYING ON ANTIOXIDANT PROPERTIES, TOTAL PHENOLS AND FLAVONOIDS IN POLLENS
}

\author{
Ingmars Cinkmanis, Fredijs Dimins, Velga Mikelsone \\ Department of Chemistry, Faculty of Food Technology, Latvia University of Agriculture, Liela iela 2, Jelgava, Latvia, \\ e-mail: ingmars.cinkamnis@llu.lv
}

\begin{abstract}
Pollen is one of the most popular beekeeping products surpassed by honey and wax. In nature there is no food analogue, which can compare to pollen in terms of those biologically active substances, which are necessary for normal development and functioning of human body. The aim of the research was to determine and compare the total antioxidants, total flavonoids, total phenolic compounds and antiradical activity content in fresh, lyophilized and dried pollen samples. Content of total antioxidants (DPPH quercetin equivalent), total flavonoids, total phenols and antiradical activity (with DPPH absorption) was determined by spectrophotometric method. Three different pollen samples were analysed - fresh pollen, dried pollen at $+42{ }^{\circ} \mathrm{C}$ and lyophilized pollen. Results of the analysis showed that the highest total antioxidant content is in fresh pollen $-29.75 \mathrm{mg} \mathrm{QC} 100 \mathrm{~g}^{-1}$, but the lowest in both dried samples.

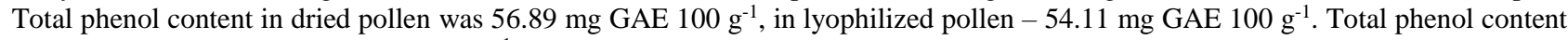
in fresh pollen was $61.64 \mathrm{mg}$ GAE $100 \mathrm{~g}^{-1}$. Both thermal treatment and lyophilisation decreased flavonoid content in pollen. Drying pollen at $+42{ }^{\circ} \mathrm{C}$ affected by lower losses of total antioxidants, total flavonoids, total phenols and antiradical activity than in lyophilisation process.
\end{abstract}

Keywords: drying, lyophilisation, pollens, total phenols.

\section{Introduction}

The chemical composition of pollen is diverse and complex. Nowadays it is used not only as a dietary ingredient, but also as an alternative medical remedy (Kroyer, 2001). Pollen contains carbohydrates, fats, proteins (composed of all the essential amino acids), minerals (containing 28 chemical elements, especially significant amounts of $\mathrm{K}, \mathrm{Cu}, \mathrm{Fe}$ and $\mathrm{Co}$ ) about 50 enzymes and hormones (Siņakovs, 2009). Natural antioxidants are also found in pollen (de Arruda et al. 2013; LeBlank et al., 2009). Vitamins A, E, C, B-vitamins, niacin, rutin, polyphenols, and selenium compounds are widely represented in pollen (Bonvehi, 2001). Pollen contains 20 times more vitamin A than, for example, carrots (Šteiselis, 2013).

There are various parameters characterizing antioxidants. Flavonoids are a significant group of plant secondary metabolites having a different biochemical and antioxidant effects. Flavonoids possess antiradical activity, thus radicals, as atomic oxygen, hydrogen peroxide, superoxide anion radical, resulting in the plant from UV radiation and natural plant metabolism, are neutralized and eliminated from the plant (Galeotti et al., 2008). Because of this essential factor people are interested in flavonoid rich foods, because human metabolic intermediates are also radicals that cause damage to cells, disrupting the phospholipid membranes. Flavonids have anti-virus, anti-allergic, anti-platelet, anti-inflammatory and antioxidant effects on the human body (Purviņš, Purviņa, 2011).

Antioxidants stops the oxidation in its early stage, preventing ongoing chain reactions, but antiradical activity begins to work later. Also, it neutralizes free radicals. Anti-radical activity is caused by a variety of compounds, including polyphenols that are capable of neutralizing the radicals (Feas et al., 2012).
Polyphenols are sum of phenol compounds in pollen. They are biologically active substances that are found in nature. Polyphenols main feature is the presence of many phenolic structures. This structure is the basis of large number and diversity of this group's unique physical, chemical and biological properties (Quidau et al., 2011).

Pollen composition depends on the plant type and pollen harvesting conditions (Almaraz-Abaraca, et al., 2004). Variable according to relative humidity of air is the water content - in freshly harvested it is $20-30 \%$. Fresh pollen must be used within a short period of time because of the increased moisture content, they begins to grow mould and microorganisms, which produce toxins are developed. For long-term storage of pollen they need to be treated - water content must not exceed $12.5 \%$, the optimal water content is $8-10 \%$ (Ritmanis, 2004). Beneficial nutritional properties of biologically active substances in various honey products, including pollen, are widely studied but rarely changes in composition and properties based on type of storage and treatment are discussed.

Most conventional way to treat pollen is to dry it in convective type dryers. Pollen is laid in a thin layer and dried at $42{ }^{\circ} \mathrm{C}$, the existing water is continuously discharged by forced ventilation (Bogdanov, 2011). Thermal drying is not the only way to achieve the desired result.

In lyophilisation process pollen is not dried by heating but by freezing it under reduced pressure. This causes sublimation - water in pollen immediately goes into the gaseous phase, skipping the liquid phase (Giordano et al., 2011). This technique is indispensable if it is required to dry heat-sensitive substances, which during drying in the oven $\left(42{ }^{\circ} \mathrm{C}\right)$ is significantly affected by temperature and lose its high-value properties (de Melo, de Almeida-Muradian, 2010). 
Pollen high-value properties, characterized by biological activity indicators such as total phenol, total flavonoids, total antioxidant content and antiradical activity, is reduced if product is dried or lyophilized (Giordano et al., 2011).

The aim of the research was to determine and compare the total antioxidants, total flavonoids, total phenolic compounds and antiradical activity content in fresh, lyophilized and dried pollen samples.

\section{Materials and Methods}

Research was carried out at the Department of Chemistry, Faculty of Food Technology at the Latvia University of Agriculture. The object of the research was bee pollen. Pollen were harvested in April of 2016 from Saldus district Ltd. „ULMUS-MEDUS”.

\section{Characterization of drying process}

Bee pollen were convective dried with air circulation at $42{ }^{\circ} \mathrm{C}$ using Memmert UFE-400 and lyophilized using Christ Freeze Dryer Alpha 1-2 LD plus at $-60{ }^{\circ} \mathrm{C}$ for 24 hours at 0.046 mbar.

Extraction of pollen samples

$1.500 \mathrm{~g}$ of fresh, dried and lyophilized pollen was extracted with $50 \mathrm{~mL}$ methanol. Extraction was carried out for 1 hour. Extract were centrifuged at $13000 \mathrm{rpm}$ in a centrifuge for $5 \mathrm{~min}$, the supernant was used for further analysis.

Determination of total phenolic content (TPC)

Total phenol compound content was determined by spectrophotometry (Kaškoniene, 2009). Method is based on phenol compound reaction with the FolinCiocalteu reagent. Coloured solution is formed, which is measured in the light absorption using a $760 \mathrm{~nm}$ wavelength. Total phenolic content levels are expressed as gallic acid equivivalents mgQE $100 \mathrm{~g}^{-1}$ dry weight (Singleton, 1999).

Determination of total flavonoids content

The total flavonoid content of pollen was determined by spectrophotometry. Method was based on the pollen flavonoids reaction with $\mathrm{AlCl}_{3}$. Coloured solution was formed, its light absorption was measured using $415 \mathrm{~nm}$ wavelength light. Total flavonoid content are expressed as quercetin equivalent mgQE $100 \mathrm{~g}^{-1}$ dry weight (Singh, 2012).

\section{Determination of total antioxidants content}

Pollen antioxidant properties was characterized by spectrophotometry (Bertoncelj, 2007). The method is based on reagent DPPH (2,2-diphenyl-1picrylhydrazyl) reaction with antioxidants by light absorption maximum of $517 \mathrm{~nm}$ wavelength. Total antioxidants content is expressed as quercetin equivalent mg QE $100 \mathrm{~g}^{-1}$ dry weight.

Determination of antiradical scavenging activity Antiradical scavenging activity was determined by spectrophotometric method with DPPH (2.2-diphenyl1-picrylhydrazyl) absorption of $517 \mathrm{~nm}$ wavelength.

Statistical analysis
The results were processed by mathematical and statistical methods (mean, standard deviation) using Microsoft Office Excel 2016.

\section{Results and Discussion}

The highest total flavonoid content was found in fresh pollen: $196 \mathrm{mg} \mathrm{QE} 100 \mathrm{~g}^{-1}$, while the lowest was in lyophilized pollen: $154 \mathrm{mg}$ QE $100 \mathrm{~g}^{-1}$ (Fig.1).

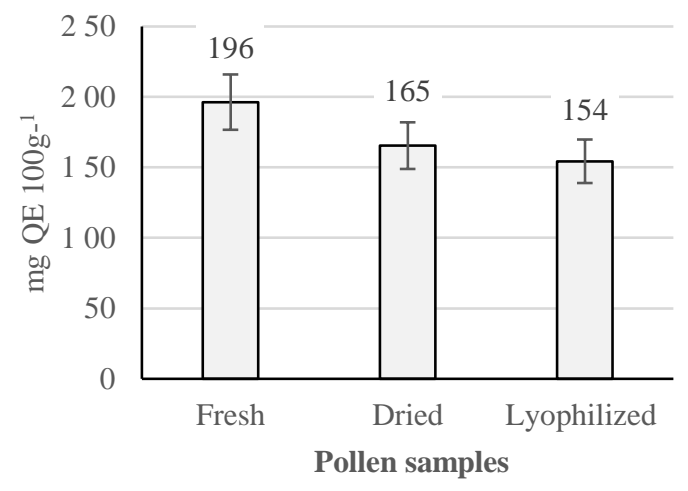

Figure 1. Content of total flavonoids

Flavonoid content in pollen is decreased by both thermal treatment and lyophilisation of pollen. Heat treatment destroyed $15.7 \%$, while the lyophilisation $21.3 \%$ of flavonoids, compared to flavonoid content in fresh pollen. When comparing the flavonoid content of the thermally treated and lyophilized pollen, differences are not significant.

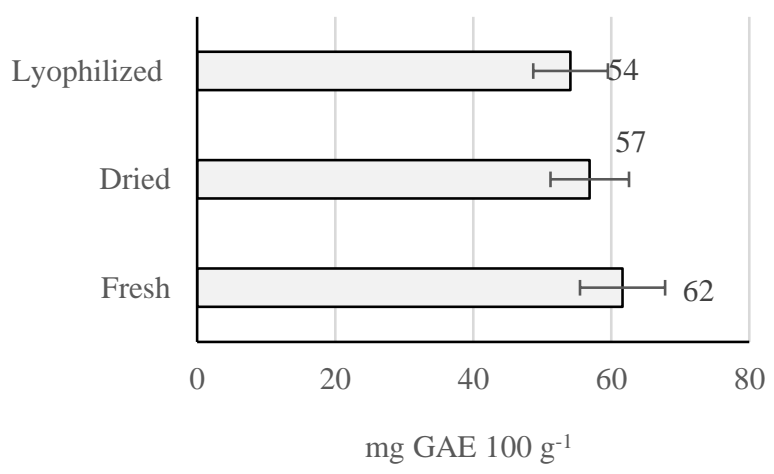

Figure 2. Content of total phenols

In dried pollen total phenol content in the dry matter is $57 \mathrm{mg}$ GAE $100 \mathrm{~g}^{-1}$, in lyophilized $54 \mathrm{mg}$ GAE $100 \mathrm{~g}^{-1}$, in fresh $62 \mathrm{mg} \mathrm{GAE} 100 \mathrm{~g}^{-1}$ (Fig. 2). The differences between the total phenolic content of dried and lyophilized pollen is similar - differing only by $2.1 \%$, which is within the method errors limits.

The highest antiradical activity was detected in dried pollen $-85 \%$, slightly lower in the freeze-dried pollen $82 \%$, while the lowest was in fresh pollen - $72 \%$ (Fig. 3). 


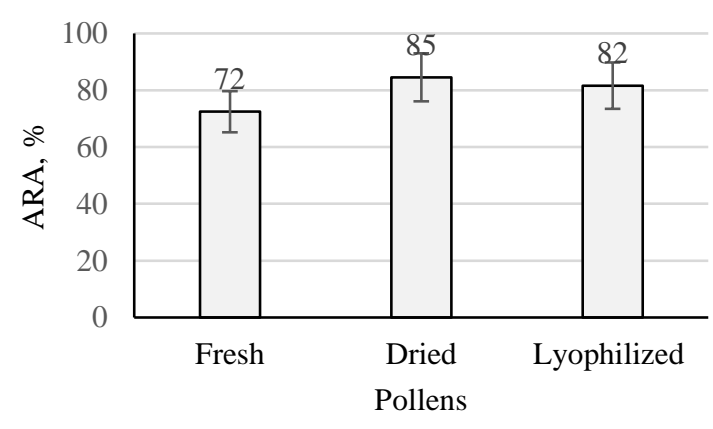

Figure 3. Antiradical scavenging activity

However, the differences between data was within error limit of the method i.e. $\pm 10 \%$. If highest and lowest error detection margin is taken in account regarding the data, then the differences are negligible.

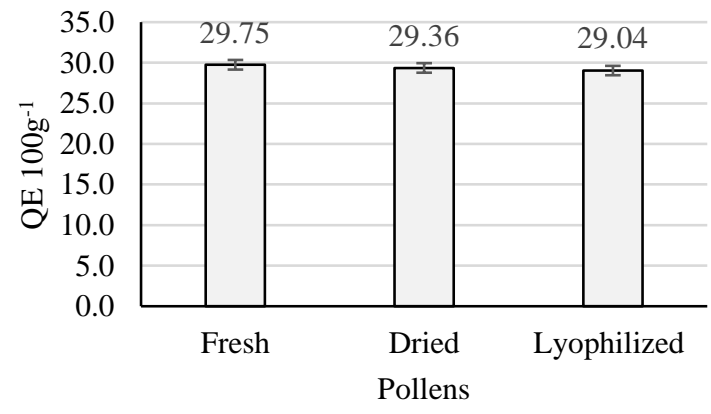

Figure 4. Content of total antioxidants

The total content of antioxidants (Fig.4) in dried and lyophilized pollen dry matter is similar - differing only by $2 \%$, which is within the margin of method error.

\section{Conclusions}

The highest total flavonoid - $196 \mathrm{mg}$ QE $100 \mathrm{~g}^{-1}$ and phenol content $-62 \mathrm{mg}$ GAE $100 \mathrm{~g}^{-1}$ was found in fresh pollen, antiradical activity in analysed samples was insignificantly higher in dried and lyophilized samples, but the total antioxidants content of all samples was similar and in all the pollen ranged from 29.04 to 29.75 QE $100 \mathrm{~g}^{-1}$.

\section{References}

1. Almaraz-Abaraca N., Campos M.G., Ávila-Reyes J.A. (2004) Variability of antioxidant activity among honeybee collected pollen of different botanical origin. Journal of Science and Technology of the Americas. No. 29, p. 574-578.

2. Bertoncelj J., Doberšek U., Jamnik M., Golob T. (2007) Evaluation of the phenolic content, antioxidant activity and colour of Slovenian honey. Food Chemistry, Vol. 105 , p. $822-828$.

3. Bogdanov S. (2011) Pollen: Nutrition, Functional Properties, Health: A Review. Bee Product Science. [accessed on 11.12.2016]. Available at: http://www.beehexagon.net/files/file/fileE/Health/Pollen Book2Review.pdf.

4. Bonvehí J.S., Torrentó M.S., Lorente E.C. (2001) Evaluation of polyphenolic and flavonoid compounds in honeybee-collected pollen produced in Spain. Journal of Agricultural and Food Chemistry. Vol. 49, p. 1848-1853.

5. De Arruda V.A.S., Pereira A.A.S., Freitas A.S., Barth O.M., Almeida-Muradian L.B. (2013) Dried bee pollen: B complex vitamins, physicochemical and botanical composition. Journal of Food Composition and Analysis, Vol. 29, p. 100-105.

6. De Melo L.I. P., de Almeida-Muradian L.B. (2010) Stability of antioxidant vitamins in bee pollen samples. Quimica Nova, Vol.33, No. 3, p. 514-518.

7. Feás X., Vázquez-Tato M.P., Estevinho L., Seijas J.A., Iglesias A. (2012) Organic bee pollen: botanical origin nutritional value bioactive compounds antioxidant activity and microbiological quality. Molecules, Vol. 17, p. 835837.

8. Galeotti F., Barile E., Curir P., Dolci M., Lanzotti V. (2008) Flavonoids from carnation (Dianthus caryophyllus) and their antifungal activity. Phytochemistry Letters. Vol. 1, p. 44-48.

9. Giordano A., Barresi A.A, Fissore D. (2011) On the Use of Mathematical Models to Build the Design Space for the Primary Drying Phase of a Pharmaceutical Lyophilization Process. Journal of Pharmaceutical Sciences, Vol. 100, Iss. 1, p. 311-324.

10. Kaškoniene V., Maruška A., Kornyšova O., Charczun N., Ligor M., Buszewski B. (2009). Quantitative and qualitative determination of phenolic compounds in honey. Chemine Technologija, Vol. 3(52), p. 74-80.

11. Кочикян А.Т., Ананикян В.В. Ерибекян М.И. (2009). Изучение антирадикальной активности некоторых лекарственных и пищевых растений [Studying of the antiradical scavenging activity of some medicinal and food plants]. Медицинская наука Армении НАНРА, 3, 127 c. (in Russian).

12. Kroyer G., Hegedus N. (2001) Evaluation of bioactive properties of pollen extracts as functional dietary food supplement, Innovative Food Science \& Emerging Technologies, Vol. 2, p. 171-174.

13. LeBlanc B.W., Davis O.K., Boue S., DeLucca A. Deeby T. (2009) Antioxidant activity of Sonoran Desert bee pollen, Food Chemistry, Vol. 115, p. 1299-1305.

14. Purviņš I., Purviņa S. (2011) Prakstiskā farmakologija [Practical pharmacology]. Zāḷu infocentrs, 896 lpp (in Latvian).

15. Quideau S. P., Deffieux D., Douat-Casassus C. L., Pouységu L. (2011) Plant Polyphenols: chemical properties, biological activities, and synthesis. Angewandte Chemie International Edition. Vol. 50(3), p. 586-621.

16. Ritmanis Z. (2004) Medus un citi biškopības produkti [Honey and other bee products] Rīga: Nordik. 264 lpp. (in Latvian).

17. Sinakovs A. (2009) Medus ārstniecības enciklopēdija [Medical encyclopedia of Honey]. Rīga: Vieda. 736 lpp. (in Latvian).

18. Singh S. (2012) Determination of Phenol \& Flavonoid Contents In Acorus Calamus. Asian Journal of Biochemical and Pharmaceutical Research. Vol.2(2), p. 388-392.

19. Singleton V.L., Orthofer R., Lamuela - Raventos R.M. (1999) Analysis of total phenols and other oxidation substrates and antioxidants by means of Folin-Ciocalteu reagent. Methods in Enzymology, 299, p. 152-178.

20. Šteiselis J. (2013) Bites un medus [Bees and honey]. Lauku Avizes raksti Nr.3 (217) 64 lpp. (in Latvian). 